\title{
Reflection of Emotions in the Phraseology of the Tatar Language
}

\author{
${ }^{1}$ Gulnara I. Khasanzyanova, ${ }^{2}$ Radif R. Zamaletdinov, ${ }^{3}$ Firuza R. Sibaeva, \\ ${ }^{4}$ Ruzilya R. Salakhova \\ 1, 2, 3,4 Kazan Federal University, Russia, 420008, Kazan, Kremlevskaya Street, 18
}

Email: firuzars@mail.ru

\section{Received: 15th December 2017, Accepted: 20th December 2017, Published: 31st December 2017}

\begin{abstract}
In the contemporary Tatar linguistics, a great interest is shown to consideration of the language as a unique cultural code of certain linguistic-cultural communities. Application of phraseological collocations that have an immediate lexical equivalent in the language in the Tatar poetry may be contextually distributed with the same adverb as their lexical equivalents. It does not add anything new to the meaning of the collocation itself, but such expansion of the boundaries of the fixed collocation may still leave its mark for the meaning in the particular context by introducing new additional shades of meaning that do not exist in its commonlanguage variant.In this paper, an attempt is made to disclose the national uniqueness of emotional experiences of the Tatar people by basing on such general scientific research methods as induction, deduction, observation, analysis and synthesis of the empirical material. Phraseological units of the Tatar language with emotionally colored components were analyzed, which makes it possible to generalize and to assess the representation of the view of the world of the Tatar people. It is proven with results of this research that the humans in the Tatar linguistic view of the world, same as in the Oriental linguistic culture, their emotions and speech aspire to be in harmony by mutually complementing each other. A serious effect of Islamic traditions is observed in the lifestyle, household, and emotions of the Tatars. Relevance. Based on comprehensive analysis of phraseological units, the national uniqueness of the world outlook is revealed, methods of nomination and sectioning of the emotional world are demonstrated, as well as the representation of the image of the human in the phraseology of the Tatar language. The results obtained in the course of the research provide the opportunity to represent the relevance for the common theory of the linguistics.
\end{abstract}

Keywords: Phraseological Units, Expressive Emotional Lexis, Emotions, Tatar Language, Emotional Condition.

\section{Introduction}

During the last several decades, the emotional sphere of the humans attracts attention of increasingly larger numbers of specialists in various fields. Emotions are considered as key categories of the psychology. However, at present, emotions are extensively studied in the field of the linguistic culturology [Shadrikov V.D., 2014]; [Krasavskij N.A., 2016]; [Rodionova G.A., 2011].

Meanings of the terms "emotions", "feelings", "affect" are not strictly fixed; there is no common understanding or accurate terminological delimitations for application of such relative notions in the science. National scientists are increasingly inclined to using the term "emotion" as a generic term. Scientists see the difficulty of studying lexis expressing emotions as their abstractness, fluidity, elusiveness in the language. The ability to emotionally react to items of the real world is a natural feature of the human which is independent of their culture of linguistic attribution [Ayupova R.A., 2015]; [Husnutdinov D.H., 2015]. That said, the lexis expressing the emotional condition as a universal concept, and it is uneasy to reveal its specificity. This is the peculiarity expressed by R.R.Zamaletdinov: "Research of emotional concepts, attempts to systematize and describe them will enable to expand the idea of the semantic field of 'emotional concepts', will provide and opportunity to identify universal and languagespecific features in the methods of their conceptualization and functioning, will enable to deeper study the system of thinking of bearers of the Tatar language, and, to a larger extent, Turkic languages. Researchers studying the emotional and sensual field of the human point at vagueness of segments shaping it, and an exact and unambiguous identification of them is hard to achieve" [Sibgaeva F.R et al., 2015]; [Denmuhametova E.N., 2016]. Analysis of phraseological units expressing the emotional condition is of great importance for modelling the human's inner world. Existence and functioning of emotions is different and unique for each people. In the Tatar linguistics, the expression of the emotional condition was highlighted in the works by Sh.A. Ramazanof, G. Akhatov, G.H. Ahunzyanov, G.S. Amirov, F.S. Safiullina, L.K. Bairamova, R.A. Yusupov, G.K. Gizatova, G.Z. Sadykova.

In this paper, phraseological units of the Tatar language with an emotional shade are examined.

The purpose of this research is a sematic reconstruction of the national world views of the Tatar people in relation to emotions that expressed through phraseological units. 


\section{Methods}

This work employed the analysis and synthesis of the empirical material, its generalization and classification. The main method of the research is the method of observation of the language material. The method includes examination of the actual material, generalization, interpretation and classification, selection of phraseological units with a shade of the emotional condition of the human. Classification of the practical material was carried out on the basis of the structural and semantic analysis. Special linguistic methods were also applied: semantic analysis method, linguistic description method, thematic classification method, statistical analysis method.

\section{Results}

Studies of the lexical semantic peculiarities of phraseological units of the Tatar language is of great significance for studying stages of development of the history of thinking related to the social matters of shaping the culture of the people, as well as for clarification of the symbiotic relationship between the artistic and the aesthetic thinking. Based on the above, we can regard the semantic development of the Tatar phraseology.

Emotions in the Tatar language are defined with terms "khis" (feeling), "toygy" (emotion), "kicheresh" (emotional experience) that represent the inner world of the human. And the substance of the inner world of the human is "jan" (soul).

"Jan" (soul) is some attribute of a living creature, a source, a symbol of the human life. At any time, jan can freely leave the human body, especially while sleeping, it can roam for a while, and then return to the body again. If jan does not return, the man dies. "The soul, as Tatars imagine, can sometimes leave the human. Usually, it happens if a man is unconscious, comatose, or sleeping, but it comes back when the man wakes up [Yusupov R.A. et al., 2015]; [Salakhova R.R. et al., 2014]; [Sibgaeva F.R. et al., 2014]".

According to beliefs of the Tatars, a distinguishing feature of the soul is its capability for fly, to soar: kubelek jan (lit., the soul like a butterfly); jan qanatlanu (the soul got wings); jan ochu (the soul is flying), etc.

In the folklore, there is an expression: "Jany jennette bulsin!" / "Jany ojmakhma bulsin!'” (Let the soul be in heaven!). The place where souls of the righteous exist blissfully was called "jennet/ojmakh" (heaven) by the people.

In the people's consciousness, the idea of the soul settled as a link between humans and the divine world. It is the existence of the soul that is indicative of vitality of the human: jan alu, jan biru (lit. to take and to give the soul) - it is of the condition of a man between life and death; jan saklau (lit. to store the soul) - means to struggle for life, to live, to exist; janun alu (lit. to take the soul away) - means to die, to kill; jan biru (lit. to give the soul away) - means to die, to breath last gasp [Bolgarova R.M. et al., 2017]; [Salahova R.R., 2017]; [Mugtasimova G.R., 2016].

In the Tatar language phraseology, the following lexical units conceptual to the lexical unit "jan" can be met:

mekhebbet - jan (love - soul): jan soygen (beloved); mekhebbet ochen jan fida kilu (lit. to give the soul for love);

rukh - jan (spirit - soul): yakhshy suz - jan azygy (lit. A good word is food for the soul.);

yorek - jan (heart - soul): chyqmagan janda omet bar (lit. If the soul has not abandoned yet, there is still hope.); qurqudan yorek yarylu (lit. The heart cracked because of fright);

tynychlyq - jan (peace - soul): janyna jon usken (calm soul); tynych jan (calm soul);

qurqu - jan (fear - soul): jan cukeru (lit. The soul will jump out.); jan ochu (lit. The soul is flying.);

kunel - jan (spiritual world - soul): qalgan kunel chykkan jan (lit. Offended soul - soul that abandoned).

Jan is often a manifestation of the inner world of the man and a bearer (vessel) of human emotiona: love, fear, happiness, wraith, sorrow, etc.: jan ernu (suffering, bitterness of the soul), jan oshu (fever, cold of the soul), jan sizlau (pain, the soul is nagging), jan echese (bitterness of the soul, offence), jan syqtau (cry of the soul), jan rekhete (delight of the soul, satisfaction of the soul, good mood), etc.

"Jan", along with the main meaning, has other semantic meanings too: janun ayamau - not to spare the life; jany bar - alive; janga yaqin - close for the soul, native; echte jan bulu - as long as I live; tere jan - living man, living soul; jan azigi - food for soul; jan bashi - for each man; jan dus - close friend; jan achuy - wraith; jan atu - aspiration; jan alu - to take life, to kill; jan koyu - be dissatisfied; jan quyu - to decease; jan soygen - beloved, etc.

As the Tatar people believe, the soul can be located in different human organs [Shcherbinina T.S. et al., 2016]; [Sibgaeva F.R. et al., 2016]; [Zagidulina A.F. et al., 2016]. In the Tatar phraseology, the location of the soul, depending on the feelings experience by the man, can be the heart, the soul, palms, a thigh, fingertip, tip of the nose: jany borin ochinda (lit. the soul on the nose tip); jany botina toshte (lit. The soul escaped to the thighs.); jany uchynda (lit. the soul on the hand).

The soul can be inflicted wounds, damaes: jan yarasy (lit. wound of the soul). A feature distinguishing the soul from the body is that the soul never gets old and has no age: jan qartaymiy (the soul does not get old); the soul is freezing: jan oshu; the soul is heating: jan jylyta; burning: jan yana, hurts: jan ernu, crying: jan yilau, moving: jan chygu, jan quzgalu, jan ochu, jan kitu. 
It is noteworthy that for the Tatar people, jan (the soul) is the utmost value and treasure: jan beyese (lit. price of the soul), jan (kunel) bayligy (treasure of the soul).

In the course of the research, phraseological units with emotional and estimative semantics were analyzed.

As the results of this research prove, the boundaries between the phraseological units and those bearing emotional and estimative semantics are not always distinct enough. Nevertheless, using the context, we managed to identify the qualitative and quantitative composition of this category.

\section{Discussion}

The research proved that the reflection of the emotional state and peculiarities of expressing emotions in the phraseology of the Tatar language is exactly the manifestation of the intellectual and emotional world of the Tatar people.

We see prospects of further researches of expression of emotions in the Tatar language in a more detailed examination of the whole system of lexis in its interaction with the culture of the people. This paper can be used as a sample to hold further researches in the field of the lexicology, linguistic culturology, phraseology that reflect peculiarities of the culture and world outlooks of the Tatar people.

Phraseology of the Tatar language is a rich treasury preserving the assessment of the emotional state of the human.

The substance of the inner world of the human is the soul. "Soul" (jan, kunel, begyr) along with axiologically ethical categories of "life" and "love" means and actualizes dominating properties of the national character.

"Jan" is localized inside the human. The emotional field of the human is represented with categories "yorek" (heart), "maturliq" (beauty), "omet" (hope), "khiyal” (dream), "sagish" (blues), among which a special place is occupied by the concept of "mekhebbet" (love). In the phraseology of the Tatar language bearing emotional and estimative semantics, the conceptual contents includes: psychic condition (mekhebbetten kunel yiliy - the soul is crying because of love); feelings (yorekmege mekhebbet - love inside the heart); physical sensations (mekhebbetle karash - a loving glance); existence of a special space around the human (mekhebbet donyasy - the world of love); embodiment (janga mekhebbet keru) - love has settled in the soul.

In the emotional conceptual field of the human, keshe (human) takes an important place of the notion of "khis", "toygy", "kicheresh" that are also represented as a fundamental vital value. The feeling of joy is often accompanied with a sensation of enlightenment of the soul and raise of life forces.

\section{Conclusion}

A research of phraseological units bearing emotional and estimative semantics in the Tatar language makes it possible to properly and exactly characterize the condition of the speaker and the situation around them. The emotional lexis is capable of reflecting the representation of thoughts, emotions, feelings of the human as a result of cognitive activities, as a result of reflecting real things or phenomena. Thus, the people and its emotional state, their reflection in the phraseology are necessary components for recreating the linguistic world outlook.

A significant effect of traditions and canons of Islam in the life, household and emotion of the Tatars. Such mental structures participated from the beginning in the cognitive process, reflected the organization of the universe in the mythological, and later, in the religious consciousness of the Tatars.

\section{Acknowledgements}

The work is performed according to the Russian Government Program of Competitive Growth of Kazan Federal University.

\section{References}

Shadrikov V.D. Vvedenie v psihologiyu: ehmocii i chuvstva. M: Logos, 2014. 156 s.

Krasavskij N.A. Emocionalnye koncepty v nemeckoj i russkoj lingvokul'turah. M.: Gnozis, 2016. 373 s.

Rodionova G.A. Emotivnaya otvlechennaya leksika v yazyke proizedenij M.YU. Lermontova: avtoref. dis. ... kand. filol. nauk. M., 2011. 23 s.

Ayupova R.A. Rol' paradoksov $\mathrm{v}$ formirovanii frazeologicheskoj edinicy kak lingvisticheskogo znaka. - Filologiya i kul'tura. Philology and Culture. 2015. №4 (42). C. 35-40.

Husnutdinov D.H. Functional and semantic of tatar language verbal sinlexis // JOURNAL OF LANGUAGE AND LITERATURE. Baku, Azerbaijan. №6 May, 2015. C. 348-350.

Sibgaeva F.R, Zamaletdinov R.R, Zamaletdinova G.F. Reflection of Tatar inner world through concepts // Journal of Language and Literature. 2015, Volume 6, Issue: 3. P. 115-118.

Denmuhametova E.N. Tatarskie frazeologizmy kak pokazatel' identichnosti tatar (na primere frazeologizmov $\mathrm{s}$ geograficheskimi terminami)// Aktual'nye voprosy issledovaniya i prepodavaniya rodnyh yazykov i literatur: sbornik materialov Mezhdunarodnoj nauchno-prakticheskoj konferencii. CHeboksary: Novoe Vremya, 2016. S. 66-72.

Yusupov R.A., Aydarova S.H., Sagdieva R.K., Harisova, G.F. Improving efficiency of teaching the Tatar language to a foreign audience. International Education Studies. 2015. Vol. 8 (5), pp. 158-164. 
Salakhova R.R., Sibgaeva F.R. "Cross-linguistic differences as a type of lexical difficulties in Russian - Tatar translations" was reviewed by 2 reviewers and got positive opinion // "Journal of Language and Literature", Baku, Azerbaijan to be published in November 30, 2014 (Vol. 5, No. 4). P. 325-328.

Sibgaeva F.R., Salakhova R.R. Space in a world view of poetic phraseology of the Tatar language // Journal of Language and Literature. 2014, Volume 5, Issue 3. P. 271-274.

Bolgarova R.M., Islamova E.A. Osobennosti funkcionirovaniya tyurkizmov $\mathrm{V}$ sravneniyah russkogo yazyka // Filologiya i kul'tura. 2017. №2(48). S. 24-31

Salahova R.R. Osobennosti perevoda ehmotivnyh frazeologizmov // Problemy i perspektivy razvitiya mnogourovnevoj yazykovoj podgotovki v usloviyah polikul'turnogo obshchestva: materialy IV Mezhdunarodnoj nauchno-prakticheskoj konferencii (25-27 maya, 2017 g.). Kazan, 2017. 458 s.

Mugtasimova G.R. Tatarskie i ujgurskie paremii kak istochnik ehtnokul'turnoj informacii // Islam i tyurkskij mir: problemy obrazovaniya, yazyka, literatury, istorii i religii: materialy VIII Mezhdunarodnoj tyurkologicheskoj konferencii (Rossiya Elabuga, 22 aprelya 2016 g.). Kazan': Izdvo Kazan.un-ta, 2016. S. 254-256.

Shcherbinina T.S., Denmukhametova E.N., Denmukhametov R.R. Landscape components during phraseologism in the Tatar language // Journal of Language and Literature. 2016. 7(2). P. 353-356.

Sibgaeva F.R., Salakhova R.R., Kirillova Z.N. Problems of affixal homonymy in the tatar language // Modern Journal of Language Teaching Methods, No 300, Ahmadabad ST, Mashhad, Iran, December, 2016. P. 120-124.

Zagidulina A.F., Gilazetdinova G.Kh., Islamova E.A. Associative fields of lexemes "homeland" and "vatan"in russian and tatar linguistic consciousness// Journal of Language and Literature. 2016. Vol. 7. No. 2. P. 289-292 